\title{
Difficulty in Predicting Performance in a Project-Based Learning Program
}

\section{Louise Chan, Minnesota State University, Mankato}

Louise Chan is currently a graduate student at Minnesota State University, Mankato pursuing her Master's in Industrial-Organizational Psychology. She earned her Bachelor's degree in Psychology from University of California, San Diego.

\section{Prof. Rob Sleezer, Minnesota State University, Mankato}

Rob Sleezer earned his Ph.D. in Microelectronics-Photonics from the University of Arkansas. He attended Oklahoma State University where he graduated with a B.S. in Computer Science and an M.S. and B.S. in Electrical Engineering. He is currently a faculty member at Twin Cities Engineering which is in the department of Integrated Engineering at Minnesota State University, Mankato.

\section{Prof. Jacob John Swanson, Minnesota State University, Mankato}

Jacob Swanson is an Assistant Professor of Engineering in the Department of Integrated Engineering at Minnesota State University Mankato and an Adjunct Assistant Professor in the Department of Mechanical Engineering at the University of Minnesota (UMN). He was previously a Research Associate in the Department of Engineering at the University of Cambridge, UK. His research interests include undergraduate engineering education, internal combustion engines and emissions, gas-phase particle synthesis, and instrumentation.

\section{Mr. Mark Ahrens, Normandale Community College}

Mark Ahrens is the current Chair of the Department of Mathematics and Computer Science at Normandale Community College where he has worked the past 11 years. Mark holds degrees in Applied Mathematics (MMath) from the University of Waterloo, Ontario, Engineering Sciences (BS) from Illinois Institute of Technology, and has completed dissertation work and graduate course work $(\mathrm{PhD})$ in Mathematics and in Aerospace Engineering and Mechanics at the University of Minnesota.

\section{Prof. Rebecca A. Bates, Minnesota State University, Mankato}

Rebecca A. Bates received the Ph.D. degree in electrical engineering from the University of Washington. She also received the M.T.S. degree from Harvard Divinity School. She is currently Professor in the Department of Integrated Engineering program at Minnesota State University, Mankato, home of the Iron Range and Twin Cities Engineering programs. 


\title{
Difficulty Predicting Performance in a Design Project Based Learning Program
}

\begin{abstract}
Project-based engineering programs, where technical learning is contextualized with design projects, provide an alternative to traditional engineering programs. Currently, one such upperdivision program relies heavily on students' lower-division pre-engineering coursework as part of the application process, which is usually taught in lectures and formal, pre-defined lab experiences. However, it is not clear that a student's success in lecture-based courses would predict success in project-based courses. Thus, it is important to study the relationship between potential performance predictors and actual performance. Not only will this allow for refinement of the selection criteria for such programs, but it will also serve to inform those who are educating and advising potential applicants for these types of programs. Broadly, as engineering design projects are core to early career success, this work could have implications for all engineering curricula. This paper examines the relationship between students' performance in their pre-engineering coursework and their performance in the upper-division project-based program. The correlations between student pre-engineering academic records and their upper division performance are reported as potential performance indicators for success in a projectbased engineering program.
\end{abstract}

\section{Introduction}

One source of concern for upper division (+2) project-based learning (PBL) programs is that most lower division courses are taught in a lecture-style format, possibly with a formal laboratory where students perform explicit steps to recreate well known results ${ }^{1}$. However, this teaching method does not yield the most optimal learning experience. In fact, students in traditional undergraduate STEM courses were 1.5 times more likely to fail in those courses than students in active learning courses ${ }^{2}$. This discrepancy suggests that traditional lecture-style classes may not be the ideal format for preparing students to understand and apply the course content. PBL, a more hands-on experience with real-world applications, provides students an alternative to the typical learning format.

Although the details of the unit of analysis will be discussed in detail later, it is appropriate to briefly define what is meant by both +2 programs and PBL programs. In this context, a +2 program refers to an upper division program designed to accept transfer students. Often such a program is part of an extended campus and may be collocated with partner institutions that offer lower division credit such as community colleges to reduce the travel or relocation burden of students. In a +2 program, students are only offered upper division courses and transfer in their lower division credits, typically from a community college. As part of PBL, students gain design experience through industry-sponsored design projects that would be typically found in a capstone design experience. When presented with a design challenge, they develop and evaluate an applicable and novel solution using the knowledge and skills learned in their courses ${ }^{3}$. In a PBL program, such experiences are integrated throughout the curriculum. While research indicates the efficacy of $\mathrm{PBL}^{3-7}$, it is unknown how well lecture based experiences in the lower division prepare students for their upper division PBL work. 
This paper investigates the appropriateness of using the lower division grades as criteria for acceptance into an upper division project based engineering program by examining the correlation between lower division grades and upper division grades at Twin Cities Engineering's (TCE) +2 PBL program of Minnesota State University, Mankato, where the curriculum is driven by overarching design projects that are supported by multiple courses and student learning experiences. We are interested in using GPA to predict students' performance in design and other related courses in a PBL setting. No study has been found by the authors relating GPA to engineering design course performance, so it is believed this is the first paper to examine the relationship between these two variables.

The paper begins with a review of the literature on project-based learning and discussion of the specific implementation of PBL involved. This is followed by a discussion of issues related to transfer student experiences. The study design is presented followed by results of the current analyses. Implications for potential future work are addressed along with concluding remarks.

\section{PBL Background}

Research has shown that engineering graduates often lack communication skills, teamwork skills, and the ability to apply technical knowledge to real-world problems ${ }^{4}$ as well as interpersonal skills, problem-solving ability, time management, leadership skills, and a clear understanding of professional ethics ${ }^{8}$. These are all qualities desired by the industry ${ }^{9}$. This is further evidenced by ABET Criterion 3 student outcomes: (d) an ability to function on multidisciplinary teams, (f) an understanding of professional and ethical responsibility, (g) an ability to communicate effectively, (h) the broad education necessary to understand the impact of engineering solutions in a global, economic, environmental, and societal context, (i) a recognition of the need for, and an ability to engage in life-long learning, and ( $\mathrm{j}$ ) a knowledge of contemporary issues ${ }^{10}$.

To address these needs, a more active approach can be adopted by faculty to enhance the student learning experience ${ }^{11,12}$. Through this approach, students undertake a particular problem in class and learn vital skills that they can apply more broadly to their projects ${ }^{13}$. The connection to the real world aspects of their design projects can motivate in-class learning. Related work on problem-based learning, which is an active learning approach typically implemented in a more traditionally structured course, has shown that students are able to actively attain knowledge, develop self-directed learning skills, gain problem-solving capability, and maintain motivation for learning ${ }^{14}$. They accomplish this while attaining leadership and management skills, critical thinking, and opportunities to apply their knowledge and skills towards industry-related projects $^{15}$. These smaller in-class problems have the same goals and similar benefits of projectbased learning and serve as practice for students to learn skills that they can apply to larger-scale projects.

In PBL, students become familiar with approaching design projects from an engineering perspective and conducting projects in a professional manner as they acquire problem-solving skills, responsibility, and ownership of the learning process ${ }^{16}$. Furthermore, PBL students have better collaboration and communication skills, application of their knowledge to practical work, 
and experience working in a professional setting ${ }^{3}$. Because of these benefits, university engineering programs have been encouraged to adopt and incorporate PBL to help students build the necessary skills to succeed in the industry ${ }^{4}$.

A study by Savage, Chen, \& Vanasupa found that project-based learning helps students better understand engineering concepts across a diverse range of topics. It allows them to take a more active role in the learning process while providing a contextual environment as well as technical knowledge. Moreover, due to its realistic applicability of solving real-world problems using engineering principles and concepts, students report that it had a significant impact on their learning experience ${ }^{17}$ and increased their motivation to study and learn ${ }^{16}$.

One way many engineering students engage in PBL is through capstone design courses, which typically provide students an opportunity to work on real-world projects ${ }^{18}$. It should be noted that many capstone design courses carry no more weight than a single individual course, although students may spend significantly more time on their projects. A brief review of design courses indicates several characteristics that support PBL and are beneficial in gaining the skills necessary for success at the university and in the workplace. PBL offers benefits that serve the industry, the students, and the faculty teaching the courses. Industry clients rated the performance of student design teams favorably in all four criteria: technical aspects, problemsolving ability, communication ability, and overall performance, with most clients satisfied with the design product created ${ }^{19}$. The students indicated that they felt a sense of ownership with the capstone design project and regarded it as an invaluable learning experience ${ }^{20}$. Design courses and projects have been shown to promote written and oral communication, business skills, project management, and critical thinking within a group setting ${ }^{21,22}$. Capstone design projects can also indicate to faculty areas in which the curriculum can be improved upon. Areas where students struggle can be emphasized in future courses or in revisions to existing courses ${ }^{23}$.

While students are attracted to the hands on nature of building instrumental skills through project-based learning and multiple design projects, they often experience a shock when they begin a curriculum where projects drive the majority of the learning process. Students may not do as well as expected, in part, because of the transition from lower division programs, where classes are more likely to be taught in lecture format. This becomes a concern when predicting their performance based on their lower division work. While students may excel at traditional lecture style courses, they could experience a difficult adjustment period to PBL. In a +2 program, this is exacerbated by the transfer process and interacting with new faculty, new expectations, and new university infrastructure. Consequentially, these factors could negatively affect the students' academic performance. While it is important to scaffold the transition to allow for inclusion of many types of student experiences, better predictors will serve to enhance the ability of faculty to support student success.

\section{Transfer Issues}

Students typically transfer into TCE from partnering community colleges and may never spend time on the main campus, although occasionally a student will join the program after completing their pre-engineering work on the main campus. Each of these students faces two transfer issues. The first, a transition into PBL with a design focus, is encountered in both cases. For students 
from partnering community colleges, there is also a transition to a four-year program while students from the main campus must adjust to an extended campus. These transitions may negatively affect students’ performance as they enter the TCE program.

Previous research has indicated that many transfer students experience "transfer shock", in which the students' GPA drops after transfer to a four-year university. Although their grades tend to recover after some time, results indicated that transfer students have lower overall grades, and were less likely to graduate than students who initiated undergraduate studies at the school ${ }^{24}$. A study by Preston examined GPA and course-completion ratios (how many credits students completed) to determine success of community college students who transferred to four-year institutions. GPAs dropped after transfer, and course completion rates fell significantly upon transfer. Overall, students did not do as well at the four-year institution as they did at their previous educational institution ${ }^{25}$. While there is evidence of transfer shock for all transfer students, there have also been inconsistent studies that question its effects and pose other factors that may be involved.

A meta-analysis of transfer shock revealed that the majority of community college transfer students experienced a drop in GPA of half a point or less. However, a third of the studies revealed that students' GPA completely recovered, a third closely recovered, and a third partially recovered ${ }^{26}$. Also, students majoring in sciences, mathematics, and business experienced a more significant drop in GPA than those majoring in humanities, arts, and social sciences ${ }^{27}$. These are considerations that need to be taken in account when investigating the effects on transfer shock, especially in the community college transfer population.

Additionally, other research has shown that performance in lower division courses is predictive of success in upper division courses. Researchers measured students' performance in community college by their transfer GPA and associate degree completion, and performance at a four-year university, measured by university GPA and bachelor degree completion. Results indicated that high performance at community college was a good indicator of later success at the transferred universities $^{30}$.

\section{Overview of the Study}

Building on the previous research described above, this exploratory study investigates whether students' performance in pre-engineering courses predicts success in upper division PBL courses for students majoring in Integrated Engineering. This unique major at Minnesota State University, Mankato is offered at TCE and Iron Range Engineering (IRE), which are located at extended campus locations. TCE is located in space at Normandale Community College in Bloomington, MN while IRE operates in Mesabi Range College in Virginia, MN. IRE was developed in 2010 as a PBL program focused on providing students with design projects sponsored and mentored by industry clients ${ }^{31}$. TCE is a sister program that replicates much of the IRE model in the metropolitan Twin Cities area.

Both are upper division programs, with students eligible to apply after completing lower division prerequisites at a community college or four-year university. Through outreach and active advising of prospective students, students are encouraged to fulfill as many of their lower 
division courses as possible prior to entering our program, as that can support their success in the program and in finishing their degree ${ }^{29}$. The application process requires students to submit their lower division grades along with two short essays. (See Appendix 1.) Furthermore, students must have a 2.5 cumulative GPA in their math, science and introductory engineering courses in order to be admitted to the program. The application includes pre-engineering prerequisites, which for the purpose of this study, serve as individual predictors to examine if specific courses contribute to the performance in certain upper division courses. Students are required to fulfill the preengineering prerequisites prior to transferring into the program. However, by the time the students graduate, they must complete all of the lower division coursework. These applications are reviewed by faculty to determine the appropriateness of each student before they are accepted into the program. Once they are, students are expected to adapt and transition into PBL courses.

Because our program takes a more active approach in preparing students for the workplace, there is strong emphasis on design and professionalism, which allows students to take ownership of the design process and create goals for their projects. Unlike traditional programs in which students work on one design project over the course of their final year or semester, students in this program gain multiple exposures to the design process by participating in a design course each of the four semesters they are in the program. Each semester, a student will typically experience a new project and team although occasionally, projects and teams may be continued from a previous semester. In design, students are assessed on their ability to complete the design process and develop a solution that meets specifications. In addition to three design credits, students enroll in three professionalism credits. In professionalism, students are assessed on all the aspects of the design project that are not design (e.g., communicating with the client, conducting a personal review, reflecting on the design process, working in teams, and understanding engineering ethics). Furthermore, each student enrolls in a one-credit seminar course where they learn and practice design and professionalism skills.

Technical learning at TCE is delivered and assessed in one credit courses called technical competencies. Each student is required to earn 32 technical credits including 6 mechanical core, 6 electrical core, and 4 general core credits. If a student is focusing in mechanical or electrical, there are two additional discipline specific advanced core credits they must take. The remaining credits are advanced technical electives and vary from student to student. Each technical competency includes a deep learning activity (DLA) which represents approximately one third of the credit. A DLA might be a literature review, an experiment, or a design. Ideally, a DLA connects technical learning to the design project. In fact, one way students are able to earn credit for a DLA is by submitting an excerpt from their final design report.

Credits Completed Each Semester

\begin{tabular}{|c|c|}
\hline 3 credits & Design (1 course) \\
\hline 3 credits & Professionalism $(1$ course) \\
\hline 1 credit & Seminar 1 course $)$ \\
\hline 1 credit & Technical Competencies $(8$ courses $)$ \\
\hline
\end{tabular}

Credits Completed by Graduating Seniors $\mathrm{x} 4$ Semesters $=$ 12 Design Credits 12 Professionalism Credits 4 Seminar Credits

32 Technical Credits

Figure 1. Credit Completion by Students 
While project-based learning is a design centric form of active learning incorporated in this program, it is not a pervasive learning method in STEM fields. Knowing that students are generally accustomed to the traditional lecture style in their lower division coursework, we are interested in what predictors enable students to successfully adapt and perform well in upper division design and related courses. That way, faculty can better assess the relationships between the lower division classes students have taken prior to transfer to prepare them for success in the program. The factors that predict success are useful information to guide our admission decisions, to provide advising to students interested in this type of program, and to inform the lower division feeder programs. Additionally, this and future analyses may support how engineering programs consider preparation for design experiences.

\section{Methods}

Transcripts from 33 current and former TCE students were collected from students who had completed at least one upper division course prior to the start of the Fall 2016 semester. A correlation analysis was used to examine the relationship between the lower division courses and upper division courses. The correlations between descriptive lower division features and their upper division success, as measured by grades, were examined. The lower division features consist of:

- Overall transfer grade point average (GPA)

- Technical GPA (science, technology, engineering courses)

- Mathematics GPA (algebra, trigonometry, calculus through differential equations, statistics)

- Communications GPA (public speaking, English composition, technical writing)

- Humanities \& social sciences GPA (e.g., economics, music, philosophy, sociology, psychology, history, art, geography, foreign languages, political science, film, anthropology)

- Individual course grades in

o General biology (if taken)

o General chemistry 1

o General physics 1

o Statics

o Dynamics

o Calculus 1

o Introduction to engineering

o Freshmen composition

- Completion of an associate degree (AA, AS, AAS) or not

- Fulfilment of Minnesota Transfer Curriculum or not

The pre-engineering prerequisites include:

- General chemistry 1

- Calculus-based physics 1 and 2

- Calculus 1 through differential equations.

- One course chosen from this list: general chemistry 2, physics 3, lab-based biology for majors, or calculus-based probability.

- Statics, dynamics, electric circuits and either intro to engineering or programming 
- English composition

The upper division descriptors examined are Design, Professionalism, and Seminar courses in addition to core classes in Mechanical Engineering and Electrical Engineering, the combined core of Mechanical and Electrical Engineering courses and Advanced Technical Electives (ATEs). The grades from all upper division courses are averaged in each category for analyses. The number of grades included in the averages for Design, Professionalism, and Seminar varied depending on whether students had graduated (4) or had completed just one upper-division semester (1). Core Competencies and Technical GPAs depend on the total number of competency courses completed by students and varied from 1 (the lowest number completed by a student in one semester) to 32 (graduates).

\section{Results}

The correlation coefficients between the lower division and upper division courses are reported in Table 1. The results showed that general chemistry had the strongest correlation to many of the upper division courses. Specifically, chemistry had the strongest relationship with Mechanical Engineering courses, followed by Overall Core classes, Advanced Technical Electives, and Overall Upper Division courses.

Table 1: Correlation of Lower Division and Upper Division Performance

\begin{tabular}{|c|c|c|c|c|c|c|c|c|c|}
\hline & $\begin{array}{c}\text { Overall } \\
\text { Upper } \\
\text { Division }\end{array}$ & Design & Professionalism & Seminar & Competencies & $\begin{array}{c}\text { ME } \\
\text { Core }\end{array}$ & $\begin{array}{c}\text { EE } \\
\text { Core }\end{array}$ & $\begin{array}{l}\text { Combined } \\
\text { Core }\end{array}$ & $\begin{array}{c}\text { Adv. } \\
\text { Technical } \\
\text { Electives }\end{array}$ \\
\hline $\begin{array}{c}\text { Overall Lower } \\
\text { Division }\end{array}$ & 0.43 & 0.14 & 0.49 & 0.42 & 0.39 & 0.59 & 0.43 & 0.58 & 0.33 \\
\hline Technical & 0.37 & 0.10 & 0.35 & 0.26 & 0.40 & 0.60 & 0.43 & 0.59 & 0.31 \\
\hline Math & 0.30 & 0.01 & 0.33 & 0.43 & 0.42 & 0.63 & 0.32 & 0.54 & 0.37 \\
\hline $\begin{array}{c}\text { General } \\
\text { Biology* }\end{array}$ & 0.36 & 0.10 & 0.15 & 0.23 & 0.38 & 0.46 & 0.43 & 0.51 & 0.40 \\
\hline $\begin{array}{c}\text { General } \\
\text { Chemistry* }\end{array}$ & $\mathbf{0 . 5 2}$ & $\mathbf{0 . 2 1}$ & $\mathbf{0 . 3 4}$ & $\mathbf{0 . 3 0}$ & $\mathbf{0 . 4 9}$ & $\mathbf{0 . 6 4}$ & $\mathbf{0 . 4 2}$ & $\mathbf{0 . 6 1}$ & $\mathbf{0 . 5 2}$ \\
\hline $\begin{array}{c}\text { General } \\
\text { Physics* }\end{array}$ & 0.17 & 0.07 & 0.30 & 0.29 & 0.17 & 0.33 & 0.23 & 0.32 & 0.10 \\
\hline Statics* & $\mathbf{( 0 . 0 4 )}$ & $\mathbf{( 0 . 0 9 )}$ & $\mathbf{( 0 . 0 1 )}$ & $\mathbf{0 . 1 3}$ & $\mathbf{0 . 1 4}$ & $\mathbf{0 . 1 1}$ & $\mathbf{( 0 . 0 1 )}$ & $\mathbf{0 . 0 5}$ & $\mathbf{( 0 . 0 0 )}$ \\
\hline Dynamics* & $\mathbf{0 . 0 6}$ & $\mathbf{( 0 . 0 4 )}$ & $\mathbf{( 0 . 0 5 )}$ & $\mathbf{( 0 . 1 4 )}$ & $\mathbf{0 . 2 2}$ & $\mathbf{0 . 2 3}$ & $\mathbf{( 0 . 0 0 )}$ & $\mathbf{0 . 1 3}$ & $\mathbf{0 . 3 5}$ \\
\hline Calculus 1* & $\mathbf{0 . 0 0 )}$ & $\mathbf{( 0 . 1 7 )}$ & 0.05 & 0.37 & 0.20 & 0.41 & 0.01 & 0.24 & 0.15 \\
\hline $\begin{array}{c}\text { Intro to } \\
\text { Engineering* }\end{array}$ & 0.10 & 0.08 & 0.10 & 0.01 & 0.07 & 0.10 & $(0.10)$ & $(0.00)$ & 0.22 \\
\hline $\begin{array}{c}\text { Freshmen } \\
\text { Composition* }\end{array}$ & 0.21 & $\mathbf{( 0 . 0 1 )}$ & 0.29 & 0.16 & 0.08 & 0.28 & 0.30 & 0.34 & 0.15 \\
\hline Communication & 0.28 & 0.18 & 0.34 & $\mathbf{0 . 5 1}$ & 0.25 & 0.34 & 0.19 & 0.30 & 0.32 \\
\hline $\begin{array}{c}\text { Humanities \& } \\
\text { Social Sciences }\end{array}$ & 0.34 & 0.16 & $\mathbf{0 . 5 6}$ & 0.32 & 0.06 & 0.08 & 0.34 & 0.25 & 0.01 \\
\hline (ndicates ind & & & & & & \\
\hline
\end{tabular}

*Indicates individual course grades

In terms of the relationship between communication skills, humanities courses were correlated with Professionalism courses and communication courses were correlated with Seminar courses. The other individual predictors were more directly connected to engineering technical knowledge. Statics, Dynamics, and Introduction to Engineering, were weakly correlated with upper division courses. The majority of the correlation coefficients between Statics and 
Dynamics and upper division courses were near or close to zero. Intro to Engineering courses had generally weak correlations with upper division courses.

Of the upper division categories, design had the weakest correlations. None of the lower division courses were predictive of performance in Design, suggesting that other knowledge or learning better predicts design learning.

Having an associate's degree and completing the Minnesota Transfer Curriculum were not indicative of success in the TCE engineering program, as measured by the student's upper division GPA.

Based on this data, there is no change in performance based on completion of a transfer degree or the Minnesota Transfer Curriculum. The data reveals almost no difference between the upper division GPA and whether or not students had completed either an associate's degree or the Minnesota Transfer Curriculum.

\section{Discussion}

This study investigated the relationship between the pre-engineering prerequisites, as part of the lower division courses, and the upper division courses to see which may be predictive of students' success in the program. The biggest takeaway from the data presented above is that there is a lack of correlation between the variables. This is meaningful because it shows that there is a weak relationship between the students' lower division grades and their upper division performances in a (+2) design centric PBL program, even though these are program prerequisites.

The individual predictor, general chemistry, was a weak predictor of upper division courses, but it is the strongest one we have found. For a prerequisite course that students are expected to take prior to entry in the Integrated Engineering major, chemistry was an unexpected predictor. For many students, chemistry is a course where they question its practicality as they do not see its value and application in their future academic courses. However, it has shown to be predictive of their performance in upper division courses.

It is possible that there is an external factor contributing to the outcome. For instance, persistence has been shown to be a major contributor for success in school ${ }^{32}$. Although students may not recognize the value of a chemistry education, they may persist and overcome any lack of motivation and difficulty of the topic to perform well in the class. This could be an alternative hypothesis that explains their performance in the upper division courses. Further research would need to be conducted to assess the source of this relationship.

Alternatively, general chemistry is a one semester course that is frequently taught in a different style than physics and calculus. Students in chemistry courses are asked to learn in a different format than physics and math. It is structured in a different way and addresses a new topic that does not foreshadow other kinds of courses. For instance, taking another physics course in a sequence would be more familiar to the student than a course in a new topic (here, chemistry, but in the future, design). This suggests that students learning a new topic in a new environment and 
how well they are able to adjust to this transition may be what is indicated here. The ability to acclimate to a new learning style may be the underlying cause of a student's successful adjustment to our program of PBL.

What is predictive are courses that involve interactions with others. Humanities courses are correlated with professionalism and Communication courses are correlated with seminar. These lower division courses may be indicative of how well students would work with clients, and their ability to relate to people and to the world. Students in this program are more successful when they have performed well in communication coursework beforehand. This extends previous research showing that the majority of students who did well in a community college English course also did well in English courses in a four year university ${ }^{25}$. Thus, a higher emphasis should be placed on the course grades in communication, humanities, and social sciences when assessing the program applications as well as the quality and depth of content in the two short essays students are required to submit.

The limitations of this study include the unit of analysis, a small sample size, and restricted GPA range. The unit of analysis is a design centric PBL program where students participate in a minimum of four design projects. It would be worth replicating this study in a more traditional program and typical senior design experiences to see if the results hold in that context. Although increasing the sample size in any study is always desired, it is not believed that a larger sample would result in substantial changes to the slope of the regression line or the correlation coefficient. The GPA variability is small because each course is graded on a scale of 0-4 and the courses were typically taken in one unit increments. The GPAs are further restricted due to the program application process which enforces a pre-engineering GPA of 2.5 with no grade less than a C- (1.67).

\section{Future Work}

Future analyses will address questions associated with subdivisions of students. Preliminary results, shown in Figure 2, indicate that there is little or no difference between students who enter the program with an associate of science degree and those who do not. Similarly, students who complete the Minnesota Transfer Curriculum do not appear to perform better than students who
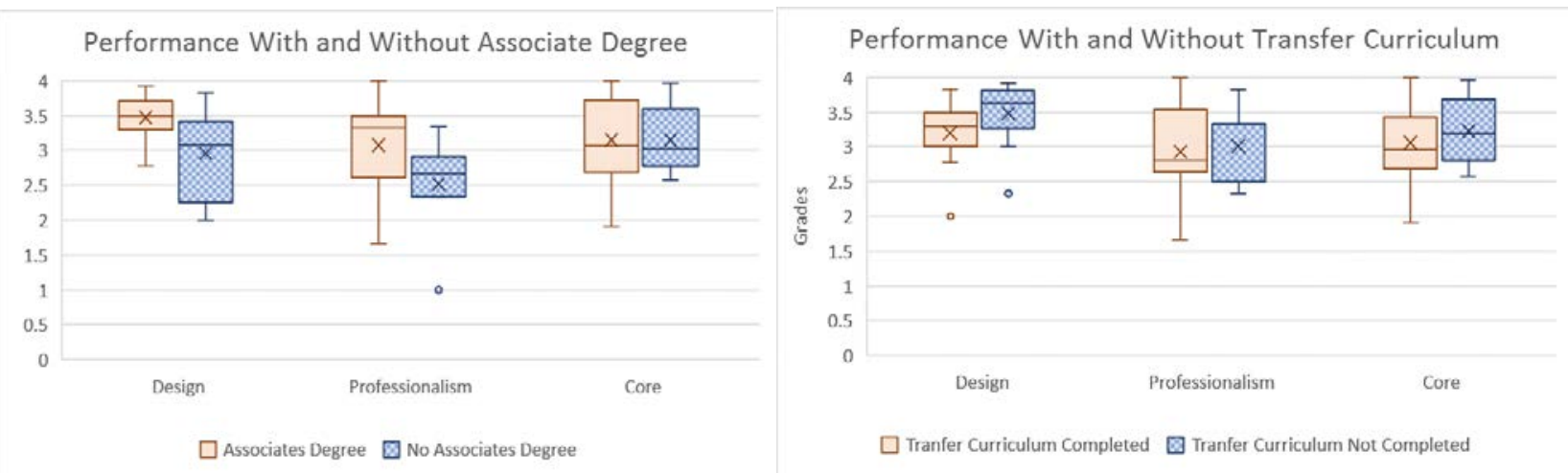

Figure 2. Performance by Completion of Associate Degree and Transfer Curriculum 
do not, as shown in Figure 2. Obtaining these results required splitting the data into sets too small to draw statistically significant conclusions so such results are considered preliminary until additional data is collected and analyzed.

As mentioned previously, TCE has a sister program in IRE. They share similar admission requirements. Investigating the predictors of success in their program could be a useful comparison to the TCE Program as they have overlapping, but different feeder schools and variations in how the lower-division courses are taught. Extending this work beyond the current setting to traditional programs would also have value. Additional research will compare the performance of students in a (+2) design based PBL programs with that of a traditional capstone design experience. It will be interesting to see whether the effects seen in our $(+2)$ design focused program are also found in traditional capstone experiences.

There may be other unaccounted for factors that may contribute to a student's success in the program. Further research could investigate peer evaluations and faculty perception data ${ }^{33}$ as measurements of success in design projects. Grades do not always correlate with faculty perception. Doing well in a class does not necessarily mean one has interpersonal skills. Peer evaluations would provide evidence of students' ability to work successfully in a team and faculty perception would allow faculty members to assess areas that may not be measured in the classroom, such as work ethic and perceived resilience. Therefore, another extension of this will be to examine faculty's perception of the student's work as predicted by lower-division indicators. Moreover, other aspects of the student's application could be further examined. As part of their application, students submit two personal statements and a letter of recommendation. It may be important to investigate these factors in order to consider the application holistically.

\section{Conclusion}

This study aimed to examine the performance predictors in a PBL program where students participate in a capstone like design experience each semester. As pre-engineering coursework is assessed as part of the student's application into the program, it is of interest to investigate how well it serves as a predictor in investigating performance in upper division courses of a PBL program. The findings revealed weak correlations among lower division GPAs and upper division design and technical grades. Although the lower division grades, collectively and individually, do not predict upper-division design grades, we still require a minimum level of exposure to the math, science, and, engineering concepts without which students are doing design outside of an engineering context. These results may also be indicative of the relationship for traditional capstone design experiences. Additional research is necessary to see if these effects hold true in that context. The implications for the study are that additional information in program applications must be included to effectively predict a student's performance.

\section{References}

1. S. Singer and K. A. Smith, "Discipline-Based Education Research: Understanding and Improving Learning in Undergraduate Science and Engineering,” Journal of Engineering Education, vol. 102, no. 4, pp.468471, 2013. 
2. S. Freeman, et al., "Active learning increases student performance in science, engineering, and mathematics," Proceedings of the National Academy of Sciences, vol. 111, no. 23, pp. 8410-8415, Jun. 2014.

3. J. W. Thomas, “A review of research on project-based learning,” Autodesk Foundation. San Rafael, CA, USA. [Online]. Available: http://www.ri.net/middletown/mef/linksresources/documents/researchreviewPBL_070226.pdf

4. J. E. Mills and D. F. Treagust, "Engineering education-Is problem-based or project-based learning the answer?," Australasian journal of engineering education, vol. 3, no. 2, pp. 2-16, Apr. 2003.

5. H. A. Hadim and S. K. Esche, "Enhancing the engineering curriculum through project-based learning," presented at 32nd Annu. IEEE Frontiers Education Conf., Boston, MA, 2002

6. C. Zhou, et al., "A problem and project-based learning (PBL) approach to motivate group creativity in engineering education.” International Journal of Engineering Education, vol. 28, no. 1, pp.3-16, 2012.

7. I. de Los Rios, et al., "Project-based learning in engineering higher education: two decades of teaching competences in real environments,” Procedia-Social and Behavioral Science, vol. 2, no. 2, pp. 1368-1378, 2010.

8. C. S. Nair, et al., "Re-engineering graduate skills-a case study,” European Journal of engineering education, vol. 34, no. 2, pp. 131-139, Apr. 2009.

9. I. Markes, “A review of literature on employability skill needs in engineering”, European Journal of Engineering Education, vol. 31, no. 6, pp. 637-650, 2006.

10. Criteria for Accrediting Engineering Programs, ABET Engineering Accreditation Commission, 2014.

11. R. M. Felder and R. Brent, "Designing and teaching courses to satisfy the ABET engineering criteria,” Journal of Engineering Education, vol. 92, no. 1, pp. 7-25, 2003.

12. P. T. Terenzini et al., "Collaborative learning vs. lecture/discussion: Students' reported learning gains,” Journal of Engineering Education, vol. 90 no. 1, pp. 123-130, Jan. 2001.

13. E. De Graaf and A. Kolmos, "Characteristics of problem-based learning," International Journal of Engineering Education, vol. 19, no. 5, pp. 657-662, 2003.

14. C. E. Hmelo-Silver, "Problem-based learning: What and how do students learn?,” Educational psychology review, vol. 16, no. 3, Sept. 2004.

15. S. Kumar and J. K. Hsiao, “Engineers learn 'soft skills the hard way': Planting a seed of leadership in engineering classes,” Leadership and Management in Engineering, vol. 7, no. 1, pp. 18-23, Jan. 2007.

16. M. Frank et al., "Implementing the project-based learning approach in an academic engineering course," International Journal of Technology and Design Education, vol. 13, no. 3, pp. 273-288, Oct. 2003.

17. R. N. Savage et al., "Integrating project-based learning throughout the undergraduate engineering curriculum,” Journal of STEM Education: Innovations and Research, vol. 8, no.3/4, pp. 15-27, 2007.

18. R. H. Todd et al, "A survey of capstone engineering courses in North America." Journal of Engineering Education, vol. 84, pp. 165-174, Apr. 1995.

19. R. L. Miller and B. M. Olds, "A model curriculum for a capstone course in multidisciplinary engineering design,” Journal of Engineering Education, vol. 83, no. 4, pp. 311-316, Oct. 1994.

20. J. A. Marin et al., "Elements of an optimal capstone design experience,” Journal of Engineering Education, vol. 88, no. 1, pp. 19, Jan. 1999.

21. C. L. Dym et al., "Engineering design thinking, teaching, and learning," Journal of Engineering Education, vol. 94, no. 1, pp. 103-120, Jan. 2005.

22. J. V. Farr et al., "Using a systematic engineering design process to conduct undergraduate engineering management capstone projects,” Journal of Engineering Education, vol. 90, no. 2, pp. 193-197, Apr. 2001.

23. A. J. Dutson et al., "A Review of Literature on Teaching Engineering Design Through Project- Oriented Capstone Courses,” Journal of Engineering Education,” vol. 86, no. 1, pp. 17-28, Jan. 1997.

24. J. R. Hill, “Transfer shock: The academic performance of the junior college transfer,” Journal of Experimental Education, vol. 33, no. 3, pp. 201-215, 1965.

25. D. L. Preston, “Interfacing Two-Year and Four-Year Transcripts for Transfer Students,” presented in $33^{\text {rd }}$ Annu. AIR Forum, Chicago, IL, 1993.

26. P. E. Diaz, "Effects of transfer on academic performance of community college students at the four- year institution,” Community/Junior College Quarterly of Research and Practice, vol. 16, no. 3, pp. 279-291, 1992.

27. C. T. Flaga, “The Process of Transition for Community College Transfer Students,” Ph.D. dissertation, Dept. of Edu. Admin., Michigan State Univ., East Lansing, MI, 2002. 
28. D. B. Monaghan and P. Attewell, “The community college route to the bachelor's degree,” Educational Evaluation and Policy Analysis, vol. 37, no. 1, pp. 70-91, Mar. 2015.

29. M. Laugerman et al., "Determining Graduation Rates in Engineering for Community College Transfer Students Using Data Mining,” International Journal of Engineering Education, vol. 31, no. 6A, p. 14481457, 2015.

30. J. C. Jones and B. S. Lee, “Moving on: A cooperative study of student transfer,” Research in Higher Education, vol. 33, no. 1, pp. 125-140, Feb. 1992.

31. R. Ulseth et al., “A New Model of Project Based Learning,” in the American Society of Engineering Education Annual Conference and Expo, Vancouver, B.C. Canada, 2011, pp. 22.78.1-22.78.13.

32. X. Wang, "Baccalaureate Attainment and College Persistence of Community College Transfer Students at Four-Year Institutions,” Research in Higher Education, vol. 50, no. 6, pp. 570-588, Sept. 2009.

33. L. J. Shuman, “The ABET 'professional skills' - Can they be taught? Can they be assessed?,” Journal of engineering education, vol. 94, no. 1, pp. 41-55, Jan 2005.

\section{Appendix 1}

Application for Program Admission

- Completed application form

- Transcripts of academic record after high school

- Essay (300-500 words) describing why you want to participate in this innovative engineering program.

- Essay (300-500 words) describing how you will contribute to the learning communities that develop within this engineering program.

- One letter of recommendation addressing your ability to succeed as an engineer, preferably from a science, math, or engineering professor or a supervisor from a job related to engineering. 